\title{
Urbach-Wiethe syndrome
}

\author{
Jyoti Ranjan Parida, ${ }^{1}$ Durga Prasanna Misra, ${ }^{2}$ Vikas Agarwal ${ }^{2}$
}

${ }^{1}$ Department of Clinical Immunology, IMS and SUM Hospital, Bhubaneswar, Odisha, India

${ }^{2}$ Department of Clinical Immunology, Sanjay Gandhi Postgraduate Institute of Medical Sciences, Lucknow, Uttar Pradesh, India

\section{Correspondence to} Dr Durga Prasanna Misra, durgapmisra@gmail.com

Accepted 23 August 2015

\section{DESCRIPTION}

A 14-year-old girl was referred for skin tightening in the fingers. She did not have Raynaud's phenomenon, gastroesophageal reflux disease or other systemic symptoms. She had had a hoarse voice since birth and was developmentally normal. She was born of a second degree consanguineous marriage. Examination revealed pearly papules around the eyelids, face (figure 1) and fingers (figure 2), and hyperkeratotic plaque on the elbows (figure 3). Oral cavity examination revealed ankyloglossia (figure 4). Systemic examination was normal. Haemogram, and liver and renal function tests were within normal limits.

The patient had a younger sibling (12 years old) with similar facial features (figure 5), elbow rash and oral cavity findings. CT of head of both siblings revealed bilateral basal ganglia calcification (figure 6). Both sisters were diagnosed to have lipoid proteinosis, or Urbach-Wiethe syndrome. Since they were asymptomatic, they were not given any medications and remained on follow-up.

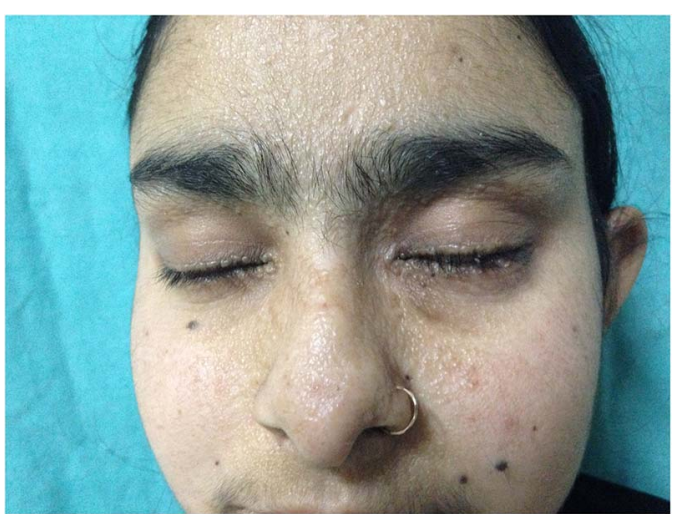

Figure 1 Elder sibling - beaded pearly papules around eyelids and on face.

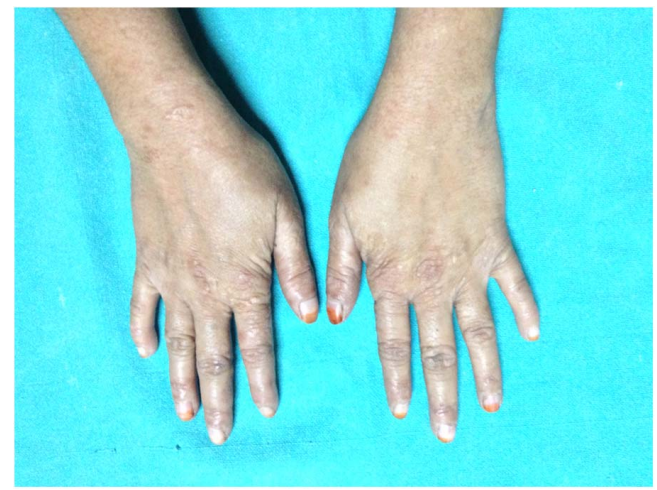

Figure 2 Elder sibling-papules on dorsum of hands and fingers.

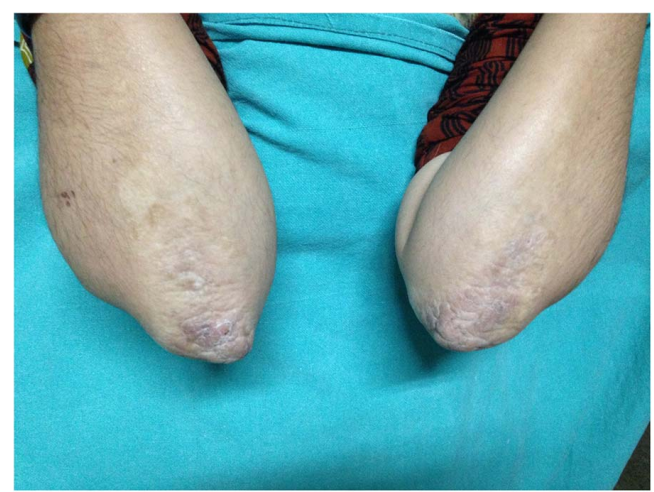

Figure 3 Elder sibling-hyperkeratotic plaque on dorsum of elbows.

Papular lesions on the face, eyes and fingers merit consideration of congenital erythropoietic protoporphyria, lepromatous leprosy and amyloidosis. Absence of painful photosensitivity ruled out erythropoietic protoporphyria in this case; and absence of hypoanaesthetic skin lesions, paresthesias and joint pains ruled out leprosy. Onset in early childhood with family history, and absence of renal and gastrointestinal tract involvement, ruled out amyloidosis. ${ }^{12}$ Hoarseness of voice with onset in early childhood merits a differential diagnosis of hypothyroidism, which can also be associated with coarse skin. However, hypothyroidism with onset from infancy is likely to be associated with mental retardation, and our patients had normal mental development. The symptom complex encountered in our patients regarding the papular lesions on the face and hands, and around the eyes, the hyperkeratotic plaque on the elbows, the ankyloglossia and hoarse voice, along with bilateral basal ganglia calcification, was characteristic of Urbach-Wiethe syndrome. ${ }^{3}$

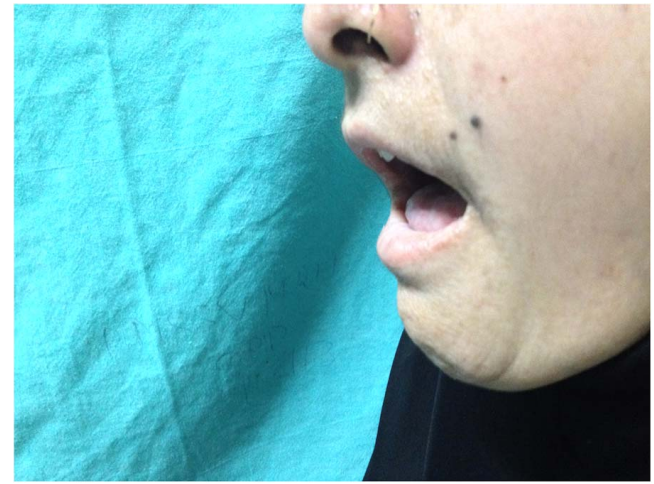

Figure 4 Elder sibling-restricted tongue protrusion. 


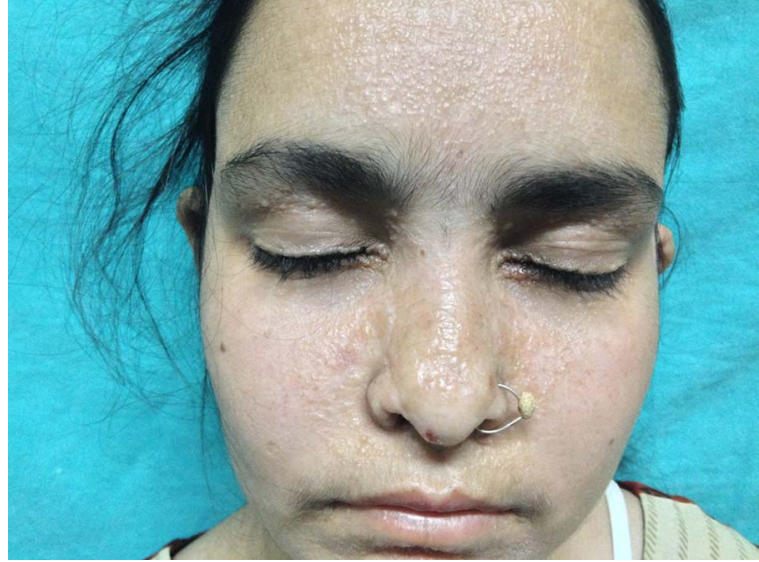

Figure 5 Younger sibling — beaded pearly papules around eyelids and on face.

Urbach-Wiethe syndrome is a rare autosomal recessive disorder due to mutation of extracellular matrix protein 1 (ECM1), leading to deposition of collagenous material in the skin and soft tissues. The characteristic facial appearance includes waxy papules, also called monoliform blepharosis, on the face, including the eyelids. ${ }^{4}$ Patients may develop hyperkeratotic plaque over sites of frequent trauma, such as the elbows. Ankyloglossia, or inability to protrude the tongue, is due to collagen deposition causing a thick frenulum. ${ }^{1}{ }^{3}$ Complications encountered in these patients include dental hypoplasia, gum hypertrophy, dryness of mouth, recurrent parotid and submandibular gland infections, and predisposition to respiratory distress during an episode of upper respiratory infection, due to thickened tongue and larynx. ${ }^{5} 6$ Neurological complications include basal ganglia calcification, usually bilaterally symmetric, which can predispose to seizures, subtle cognitive abnormalities ${ }^{7}$ and, rarely, spontaneous intracerebral haemorrhage. ${ }^{8}$ Usually, patients have a normal lifespan. Anecdotal reports suggest improvement in skin features with acitretin; its teratogenic potential merits cautious use in young females.

\section{Learning points}

- Urbach-Wiethe syndrome is a rare autosomal recessive disorder predisposing to increased collagen deposition in the skin and soft tissues.

- Characteristic features include monoliform blepharosis, ankyloglossia and bilateral symmetric basal ganglia calcification.

- It is important to recognise this rare non-life-threatening syndrome to avoid unnecessary investigations.

Contributors JRP, DPM and VA contributed to the conception and design, acquisition of the data, analysis and interpretation of the data, and final approval of the version to be published. JRP and DPM drafted the article. VA critically revised the article for important intellectual content.

Competing interests None declared.

Patient consent Obtained.

Provenance and peer review Not commissioned; externally peer reviewed.

\section{REFERENCES}

1 Hamada T. Lipoid proteinosis. Clin Exp Dermatol 2002;27:624-9.

2 Kucuk U, Erdogan IG, Bayol U, et al. Urbach-Wiethe disease (lipoid proteinosis). Indian J Pathol Microbiol 2012;55:375-6.

3 Holme SA, Lenane P, Krafchik BR. What syndrome is this? Urbach-Weithe syndrome (Lipoid proteinosis). Pediatr Dermatol 2005;22:266-7

4 Callizo M, Ibanez-Flores N, Laue J, et al. Eyelid lesions in lipoid proteinosis or Urbach-Wiethe disease: case report and review of the literature. Orbit 2011;30:242-4.

5 Rallis E, Balatsouras DG, Papadakis P, et al. Urbach-Wiethe disease. Int J Pediat Otorhinolaryngol Extra 2006;1:1-4

6 Sargenti Neto S, Batista JD, Durighetto AF, Jr. A case of oral recurrent ulcerative lesions in a patient with lipoid proteinosis (Urbach-Wiethe disease). $\mathrm{Br} J$ Oral Maxillofac Surg 2010;48:654-5.

7 Siebert M, Markowitsch HJ, Bartel P. Amygdala, affect and cognition: evidence from 10 patients with Urbach-Wiethe disease. Brain 2003;126:2627-37.

8 Messina MJ, Nuzzaco G, Barbieri A, et al. Spontaneous intracerebral hemorrhage in Urbach-Wiethe disease. Neurology 2012;79:1740-1.
Figure 6 Bilateral basal ganglia calcification (black arrow) in both siblings seen on non-contrast CT of the head.

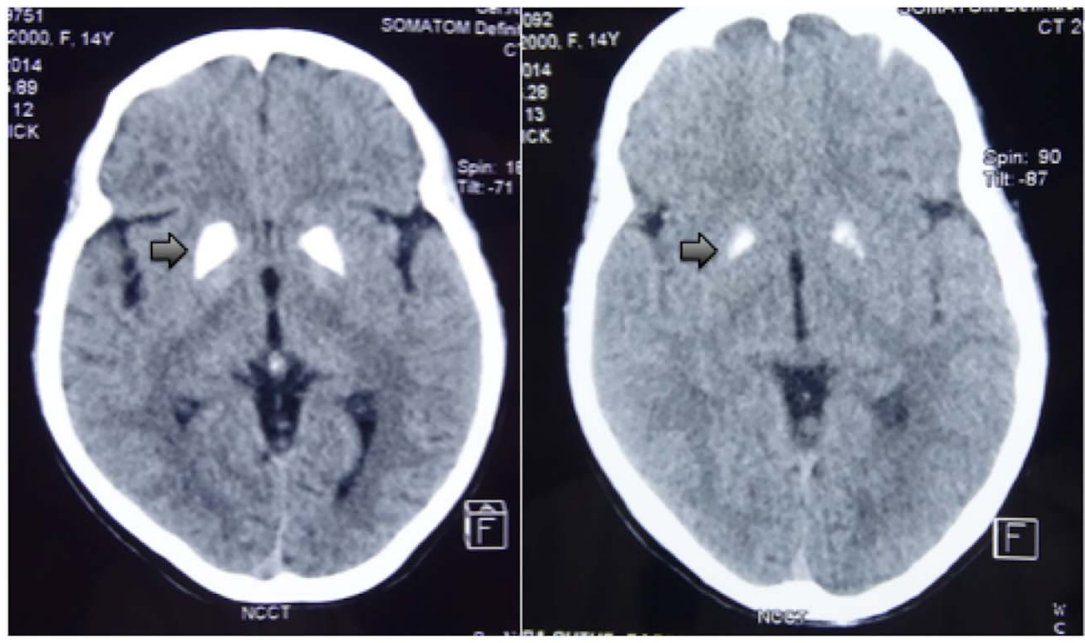

OLDER SIBLING
YOUNGER SIBLING 
Copyright 2015 BMJ Publishing Group. All rights reserved. For permission to reuse any of this content visit http://group.bmj.com/group/rights-licensing/permissions.

BMJ Case Report Fellows may re-use this article for personal use and teaching without any further permission.

Become a Fellow of BMJ Case Reports today and you can:

- Submit as many cases as you like

- Enjoy fast sympathetic peer review and rapid publication of accepted articles

- Access all the published articles

- Re-use any of the published material for personal use and teaching without further permission

For information on Institutional Fellowships contact consortiasales@bmjgroup.com

Visit casereports.bmj.com for more articles like this and to become a Fellow 